\title{
List of Tables and Boxes
}

\section{TABLES}

Table 1.1 Examples of wage problems among suppliers of brands

Table 2.1 Wage items in NGO codes of conduct, benchmarks or initiatives

Table 2.2 Examples of wage items in workers' representatives' programmes

Table 2.3 Examples of employers' initiatives on wage issues

Table 2.4 'Fair wage' initiatives by national and local authorities

Table 3.1 The 12 fair wage dimensions

Table 3.2 Summary of fair wage dimensions, indicators and relevant questions

Table 3.3 Evaluation system: the fair wage matrix

Table 4.1 Performance of Companies A and B on fair wage dimensions 100

Table 4.2 Minimum wage compliance in Companies A and B, $2008 \quad 103$

Table 4.3 Average wage in Companies $\mathrm{A}$ and $\mathrm{B}$ and industry prevailing wage, 2007

Table 4.4 Companies A and B wages and performance, 2005-2007 111

Table 4.5 Wage costs progression, Companies $\mathrm{A}$ and $\mathrm{B}$, China, 2005-2007

Table 4.6 Evaluation of the fair wage performance of Companies $\mathrm{A}$ and $\mathrm{B}$

Table 5.1 Compliance on legal wage issues

Table 5.2 Low wage problems

Table 5.3 Pay systems and wage adjustments

Table 5.4 Communication and social dialogue on wages

Table 6.1 Main features of Companies 1,2 and 3

Table 6.2 Minimum wage payment in the three companies, 2008

Table 6.3 Living wage in the three companies 
Table 6.4 Prevailing monthly wage (in RMB) in the three companies, 2008

Table 6.5 Structure of wages in the three companies, $2008 \quad 158$

Table 6.6 Average wages (in RMB) by categories of workers, $2008 \quad 162$

Table 6.7 Use of a pay grid 163

Table 6.8 Non-monetary benefits and paid holidays 164

Table 6.9 Paid public holidays under the law, China, 2009 165

$\begin{array}{ll}\text { Table } 6.10 \text { Payment of overtime } & 166\end{array}$

Table 6.11 Fair wage performance of the three companies 173

$\begin{array}{ll}\text { Table 6.12 Workers' and managers' fair wage assessment } & 176\end{array}$

Table 6.13 Workers' and managers' assessments of various fair wage dimensions

Table 6.14 Anti-crisis measures taken by national authorities, $\begin{array}{ll}\text { China, 2009-2010 } & 181\end{array}$

Table 6.15 Reactions to the crisis in the three companies 189

Table 6.16 Main effects on fair wages expected from the crisis 193

Table 7.1 Fair wage issues covered or missing at international level 203

Table 7.2 New proposed benchmarks on fair wages 211

\section{BOXES}

Box 3.1 Definition of fair wages 66

$\begin{array}{lll}\text { Box 6.1 Legal regulations on working hours, China, 2009 } & 167\end{array}$

Box 6.2 Legal regulations on social dialogue, China 171 